\title{
Sedimentology and Mineralogy of Surface Formations of the Mossendjo Area (Republic of Congo): Paleoenvironmental and Paleoclimatic Implications
}

\author{
Jude Nogelvi Ngakosso Ngolo1,2, Hilaire Elenga ${ }^{1,2 *}$, Mambou Jean Romuald ${ }^{2}$, \\ Malounguila Ganga Dieudonné 2 , Malanda Edmond ${ }^{1}$ \\ ${ }^{1}$ Laboratory of Geosciences, Faculty of Science and Technology, Marien Ngouabi University, Brazzaville, Congo \\ ${ }^{2}$ Geological and Mineral Research Center (CRGM), Brazzaville, Congo \\ Email: *hilaire_elenga@yahoo.fr
}

How to cite this paper: Ngakosso Ngolo, J.N., Elenga, H., Romuald, M.J., Dieudonné, M.G. and Edmond, M. (2021) Sedimentology and Mineralogy of Surface Formations of the Mossendjo Area (Republic of Congo): Paleoenvironmental and Paleoclimatic Implications. Open Journal of Geology, 11, 471-493.

https://doi.org/10.4236/ojg.2021.1110025

Received: June 25, 2021

Accepted: October 19, 2021

Published: October 22, 2021

Copyright $\odot 2021$ by author(s) and Scientific Research Publishing Inc. This work is licensed under the Creative Commons Attribution International License (CC BY 4.0).

http://creativecommons.org/licenses/by/4.0/

\section{(c) (i) Open Access}

\begin{abstract}
Studies undertaken at several sites in the Congolese basin and in the Chaillu massif are helping to reinterpret the sedimentological formations known as cover formations, which are widely exposed in Central Africa. This article presents the results of granulometric, morphoscopic, mineralogical and chemical analyzes obtained at three sites in the Chaillu. Gronulometric analysis indicates that the sands at the three sites are rated medium to high. The cumulative curves are essentially sigmoidal with regular and spreading slopes. This facies indicates that the deposition took place due to a banal and moderate variation in the competence of the carrier current. The morphoscopy of the quartz grains shows that they are mainly angular and shiny. These data reflect a relatively close source and transport by water. The synthesis of lithological, granulometric, petrographic and geochemical analyzes allowed us to highlight three episodes of deposits in the Mossendjo area: the first is characterized by a channel-type fluvial system marked by deposits from the hospital borehole and from the station; the second, which is alluvial, corresponds to the clogging of the channel. These two alluvial phases are overcome by a third, fluvial, channel-type episode, the end of which is marked by the establishment of the yellow formation. The vertical and lateral organization at the outcrop of this yellow formation has the same characteristics as those described earlier and in the sub-region where it was attributed to the wind-generated cover formation. This study thus highlights the existence of a wet phase during which two fluvial systems of non-contemporary channel types developed which overlap.
\end{abstract}




\section{Keywords}

Sedimentology, Fluvial System, Paleoenvironment, Mossendjo, Congo

\section{Introduction}

Superficial formations are omnipresent in the Republic of the Congo as in all tropical regions where this abundance is classically attributed to the prevalence of hot and humid climatic conditions potentially generating powerful weathering profiles (provided that they persist over long periods). In Congo, they appear in the Chaillu massif and elsewhere. Numerous soil studies have been carried out in this area [1]-[8]. These studies made it possible to know the morphology, texture, mineralogy and geochemistry of these formations.

In Western Central Africa (Congo, Gabon, DRC), a long-standing consensus exists among geologists [9] [10] [11] [12] to acknowledge that the superficial formations have a very great diversity of appearance, but a remarkable consistency in the organization, this including, the systematic presence of a horizon of soft surface of orange-yellow hue.

The yellow formation has been the subject of several studies. Recent geological work is that of [11] [13] in Gabon and that of [12] [14], and [15] in Congo. In the Republic of Congo, this work highlights the aeolian nature of the deposits in the Pointe-Noire and Brazzaville areas [12]. However, despite these results, some localities remain to be studied to better understand the sedimentary dynamics of this formation. It is within this framework that the present study is being carried out in Mossendjo. The objective is to better understand the origin of the surface formations in this region

\section{Study Materials and Methods}

\subsection{Materials}

\section{Location and Geological Context of the Study Area}

The present work was carried out in the district of Mossendjo, located in the southwest of the Republic of Congo (Figure 1).

The climate of this zone is of the Gabonese sub-climate type which is related to the Guinean forest climate [6]. The study area is characterized by two seasons: a rainy season which extends from September to May with a small dry season in February, which lasts one to three weeks depending on the year and a large dry season which runs from June to mid-September. The rains are more abundant during the months of October and November [8]. It is characterized by a high rainfall of 1600 to more than $2000 \mathrm{~mm} /$ year, with little annual variations. Temperatures vary between $21^{\circ} \mathrm{C}$ and $27^{\circ} \mathrm{C}$. Relative humidity is high. The average value of the humidity varies between $80 \%$ and $90 \%$.

The vegetation of Mossendjo is of the dense humid forest type. There are also areas of savannah, some of which are due to anthropic action, others to a variation 


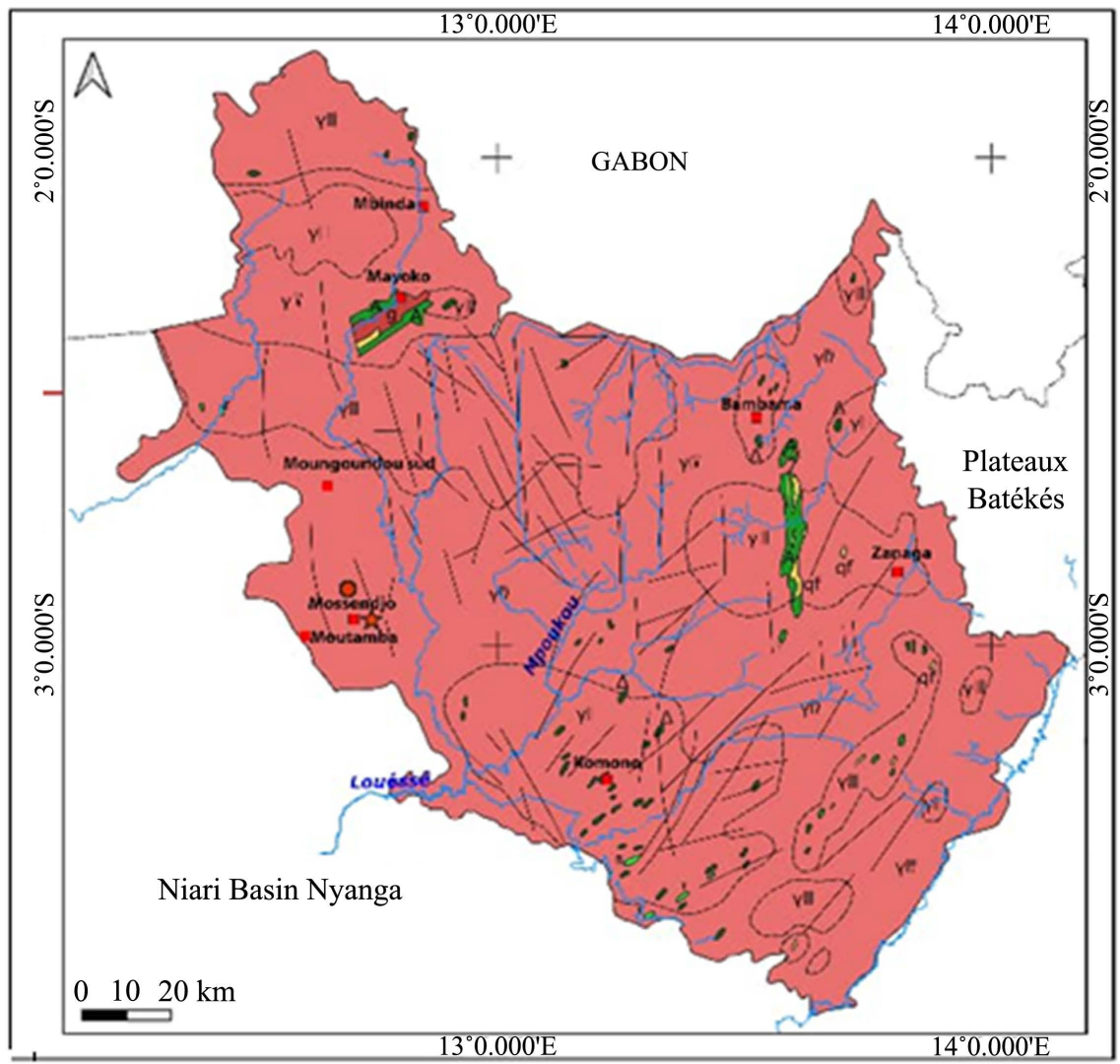

Figure 1. Geological context and location of the study area [16].

in the nature of the soil which, being very sandy, does not favor the maintenance of the forest [6]. The rainforest, made up of a large number of humid species, occupies the largest area. This vegetation is a function of the pedological nature, which itself depends on the geological identity of the region.

Geologically, the lithology of the Chaillu massif is dictated by granitizations, intrusions and metamorphisms [3] [16] [17] (Figure 1).

A first granitization gave rise to two types of granitoid: a heterogeneous granodiorite which is in the form of ankeritic granite or either in the form of granodiorite or dunite with biotite and a calc-alkaline monzonitic granite which occurs in two variants: granite leukocratic sub-orthosic alkaline or in the form of a granite with migmatitic or porphyroid facies with biotite or amphibole; a second granitization linked to an ultimate pegmatic phase giving rise to two main types of pegmatites, a leucocratic pink intra-botholitic pegmatite and a white extra-batholitic pegmatite with muscovite and tourmaline in a lenticular vein. The metamorphic formations are found in the northwest and the east of the massif. They are made up of quartzites; amphibolites, micaschists and gneisses. Basic (dolerites) and ultrabasic (pyroxenites) intrusions are noted within the Chaillu massif.

Numerous soil studies carried out in the Chaillu [1] [4] [5] [6] [7] show that the surface formations in this zone are alterites. These authors have highlighted three levels in these formations: 
- The surface horizon or A horizon, consisting only of loose and fine-textured materials; characterised by its great homogeneity of texture, structure and colour. The colour of the surface horizon varies from yellow ochre to red ochre. This is characteristic of ferralitic soils. The constituent elements do not vary noticeably throughout the entire thickness.

- The gravel horizon (stone line) containing coarse elements of various shapes and sizes.

- The weathering horizon or $\mathrm{C}$ horizon, in which different soil horizons are differentiated in a material which appears as a whole to have evolved in situ.

[8], in the study of the soils of southern Mossendjo in comparison with the soils described by [6] shows certain homogeneity in the succession of horizons, however the nature and thickness of the gravelly horizons remain very variable.

\subsection{Study Method}

The methodology consisted of the field study and laboratory analyses. The field study consisted in identifying and describing the formations which outcrop on the one hand and the cuttings resulting from the boreholes in the Mossendjo area. Three (3) lithostratigraphic logs were surveyed on three outcrops and two drillholes, and then sixty-eight samples were taken for laboratory analyses. In the laboratory, the study consisted in carrying out a sedimentological analysis which includes granulometric analysis (by sieving and by sedimentometry), mineralogical, morphoscopic and chemical. The granulometric, morphoscopic, mineralogical and chemical analysis were carried out at the sedimentometry laboratory of the Geological and Mineral Research Center (CRGM) of Brazzaville, Republic of Congo.

The particle size analysis was performed by sieving for the coarse fraction and by sedimentometry with a Robinson pipette for the pelitic fraction. After drying in the open air and then at $105^{\circ}$ in an oven, the samples taken in the field were washed and the coarse fraction was collected. The coarse fraction was submitted to a particle size analysis by sieving on a column of 12 sieves in AFNOR progression, with decreasing mesh size downwards $(4 \mathrm{~mm}, 2 \mathrm{~mm}, 1 \mathrm{~mm}, 0.500 \mathrm{~mm}$, $0.315 \mathrm{~mm}, 0.250 \mathrm{~mm}, 0.200 \mathrm{~mm}, 0.180 \mathrm{~mm}, 0.125 \mathrm{~mm}, 0.080 \mathrm{~mm}, 0.063 \mathrm{~mm}$ and $0.045 \mathrm{~mm}$ ). The particle size parameters obtained were interpreted according to the standards of [18].

Morphoscopic analysis was performed using a binocular magnifying glass, following the method of [19]. The chemical analysis consisted of determining the total carbon according to the method of [20] and total nitrogen.

The mineralogical analysis of the samples was carried out at the Geochemistry, Mineralogy and Petrology Department of the Faculty of Geology of the University of Warsaw (Poland) using the X'Pert PRO MPD powder diffractometer (PANalytical BV-The Netherlands) in Bragg-Brentano configuration. The pelite samples were used for characterization by X-ray diffraction on raw powder. The diffraction measurements were carried out on an XPert PROMPD 
PAN analytical diffractometer, operating at $40 \mathrm{kV}$ and $30 \mathrm{~mA}$, using the $\mathrm{K} \_\alpha$ line of cobalt of length $\lambda=1.789 \AA$. Data were recorded over angular domains ranging from $4^{\circ}$ to $78^{\circ}$ for the raw powder sample and from $3.8^{\circ}$ to $56^{\circ}$ for the phyllite fraction. The results obtained for each analysis (particle size, morphoscopic and chemical) are distributed along the profile to follow their vertical changes.

\section{Results}

\subsection{Results of the Field Study}

\section{Description of the hospital borehole}

The macroscopic description of the cuttings of the hospital borehole made it possible to distinguish from top to bottom an alternation of sandy, silty and clayey facies of varying thickness (Figure 2).

\section{Description of the borehole of the train station}

The macroscopic description of the cuttings of the borehole of the Mossendjo train station made it possible to distinguish from top to bottom sandy and mixed facies (Figure 3).

\section{Description of the outcrop of the train station}

The outcrop of the Mossendjo train station has a homogeneous appearance due to its yellow colour. It is dominated by sandy and gravelly facies (Figure 4).

\subsection{Results of the Laboratory Study}

\subsubsection{Granulometric Analysis}

The cumulative grain size curves of the sandy fractions of the various boreholes (Figure 5 and Figure 6) of the train station and the hospital are sigmoidal, with

\begin{tabular}{|c|c|c|c|c|c|}
\hline 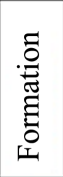 & $\begin{array}{l}\bar{D} \\
\vec{d}\end{array}$ & 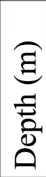 & 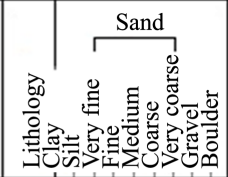 & $\frac{\mathscr{e}}{\frac{0}{2}}$ & Description of facies and remark \\
\hline 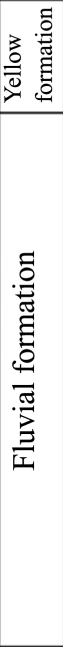 & 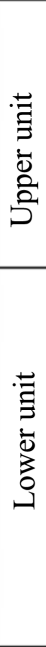 & $\begin{array}{l}5 \\
6\end{array}$ & ים: & $\begin{array}{l}\text { MOS-H01 } \\
\text { MOS-H02 } \\
\text { MOS-H03 } \\
\text { MOS-H04 } \\
\text { MOS-H05 } \\
\text { MOS-H06 } \\
\text { MOS-H07 } \\
\text { MOS-H08 } \\
\text { MOS-H09 } \\
\text { MOS-H10 } \\
\text { MOS-H11 } \\
\text { MOS-H12 }\end{array}$ & $\begin{array}{l}\text { Humic clay-sandy silts, black (current soil) } \\
\text { Yellow sandy clay silts } \\
\text { Very plastic, ocher-red clays } \\
\text { Clay-sandy silts with red lateritic gravels } \\
\text { Very coarse sand with quartzite gravels } \\
\text { Red medium sand } \\
\text { Coarse red sands } \\
\text { Very coarse red sand } \\
\text { Red medium sand } \\
\text { Gravelled sands (top of the groundwater) } \\
\text { Coarse red sands }\end{array}$ \\
\hline
\end{tabular}

Legend: Gravel

Figure 2. Lithological log of the Mossendjo hospital site. 


\begin{tabular}{|c|c|c|c|c|c|}
\hline 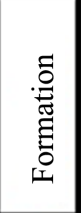 & $\begin{array}{l}\bar{d} \\
\stackrel{0}{0}\end{array}$ & 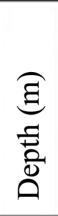 & 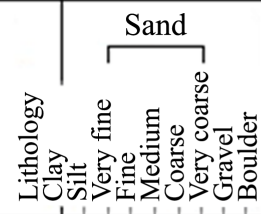 & 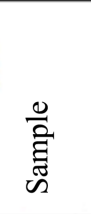 & Description of facies and remark \\
\hline 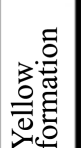 & & 0 & & $\begin{array}{l}\text { GA-1 } \\
\text { GA-2 }\end{array}$ & $\begin{array}{l}\text { Fine clayey black sands, current soil } \\
\text { Fine yellow clay sands }\end{array}$ \\
\hline 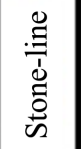 & 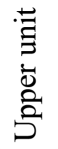 & & & $\begin{array}{l}\text { GA-3 } \\
\text { GA-4 }\end{array}$ & $\begin{array}{l}\text { Red medium sands } \\
\text { Medium sand red wine, very rich in laterite }\end{array}$ \\
\hline 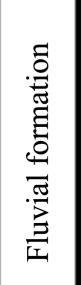 & 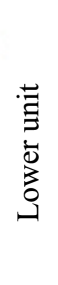 & & & $\begin{array}{l}\text { GA-5 } \\
\text { GA-6 } \\
\text { GA-7 } \\
\text { GA-8 }\end{array}$ & $\begin{array}{l}\text { Red medium sands } \\
\text { Coarse red sands } \\
\text { Very coarse red sands } \\
\text { Red medium sand }\end{array}$ \\
\hline 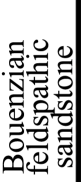 & & 40 & & GA-9 & Feldspathic sandstone (bed rock) \\
\hline
\end{tabular}

Legend: Gravel

Figure 3. Lithological log of the site of the Mossendjo train station.

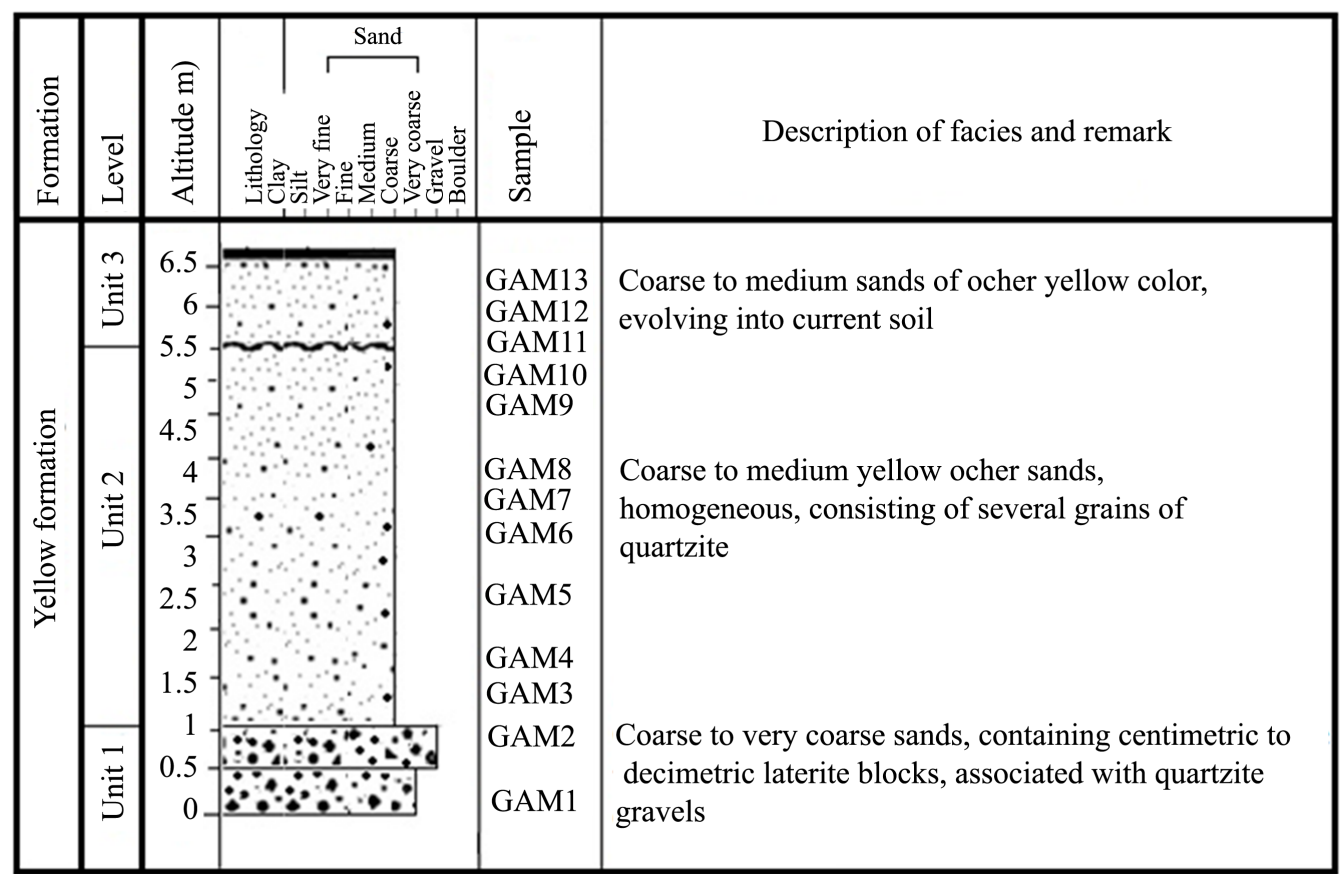

Figure 4. Lithological log of the outcrop of the Mossendjo train station. 


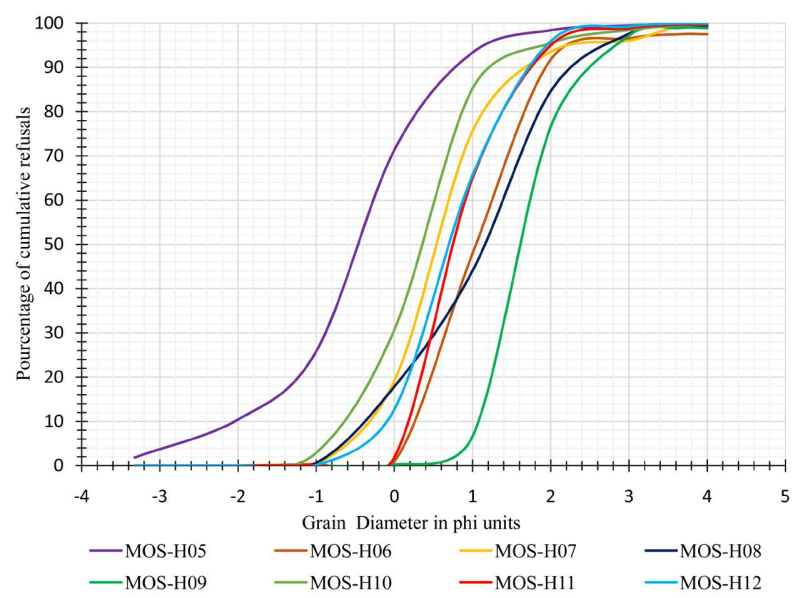

(a)

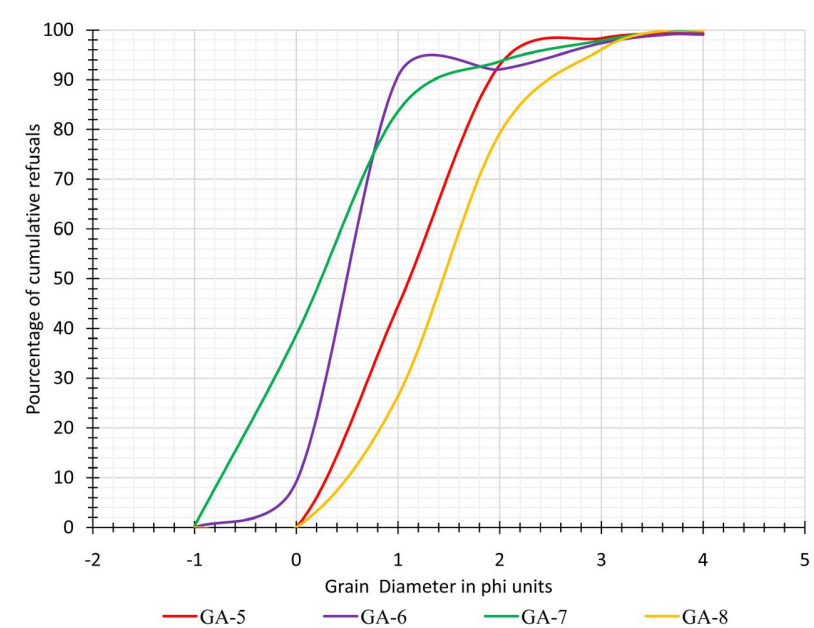

(c)

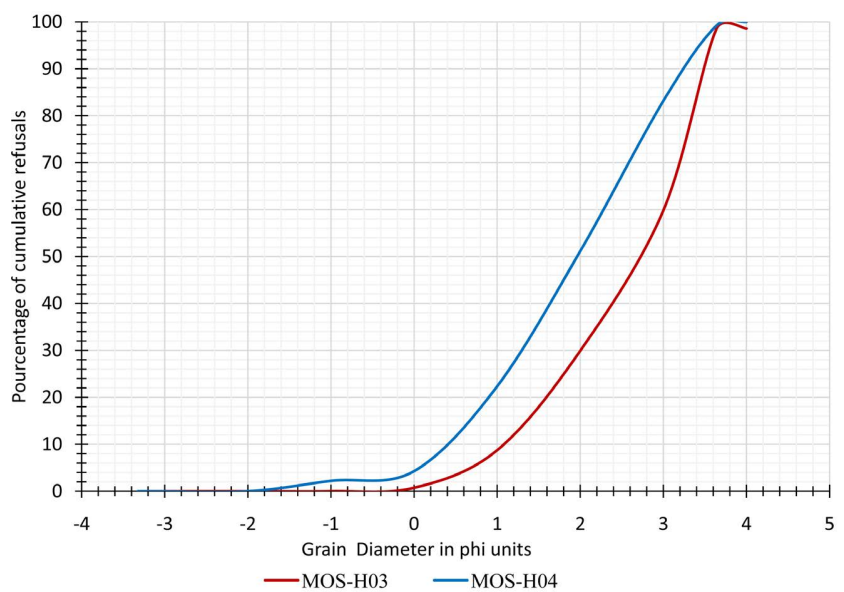

(b)

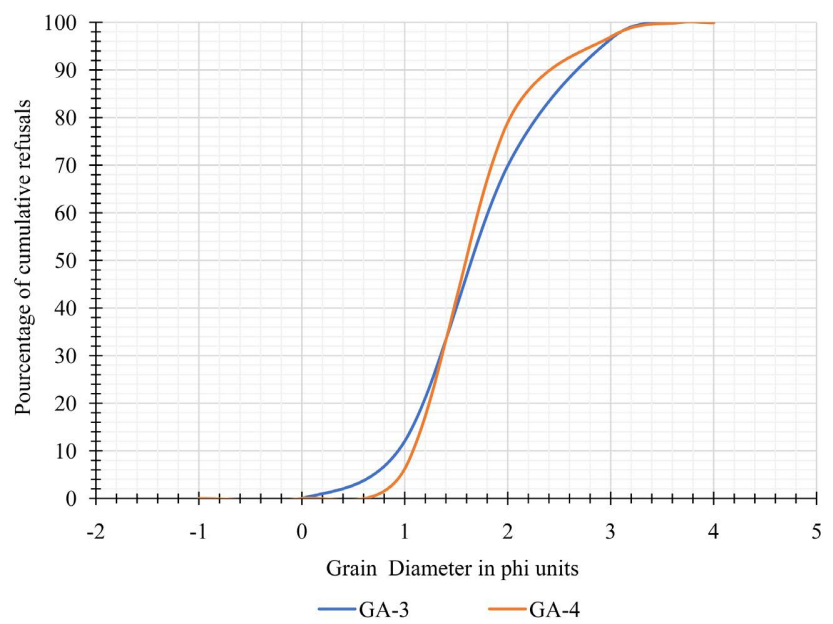

(d)

Figure 5. Cumulative granulometric curves of borehole. Hospital ((a), (b)), train station ((c), (d)).

regular to moderately straightened slopes except that of the GA-7, GAM1 and GAM2 levels which show a logarithmic shape, but with a steeper slope (Figure 5(c), Figure 6(a)).

\section{Granulometric parameters}

The granulometric indices or percentiles were determined from the cumulative curves. They were used to calculate, according to the formulae of [21], the following sieve size parameters: mean, standard deviation or grading index and asymmetry. The determination of these parameters made it possible to characterize the sands of the samples from the drilling sites.

The log of the hospital borehole reveals two grain size facies, in the upper unit the fine and medium sand facies (Table 1). In its lower unit at heights of 37.6, $54,82,83$, and $84 \mathrm{~m}$ we observe coarse sands and gravels, the medium sands at heights of 47, 61 and $77 \mathrm{~m}$.

The log of the train station borehole shows that at elevations of 9.4 and 28.2 $\mathrm{m}$, the granulometric facies are coarse to gravely sand. The granulometry indicates medium sands at heights of 1, 14.1, 18.8, 23.5 and $37.6 \mathrm{~m}$ (Table 2). 


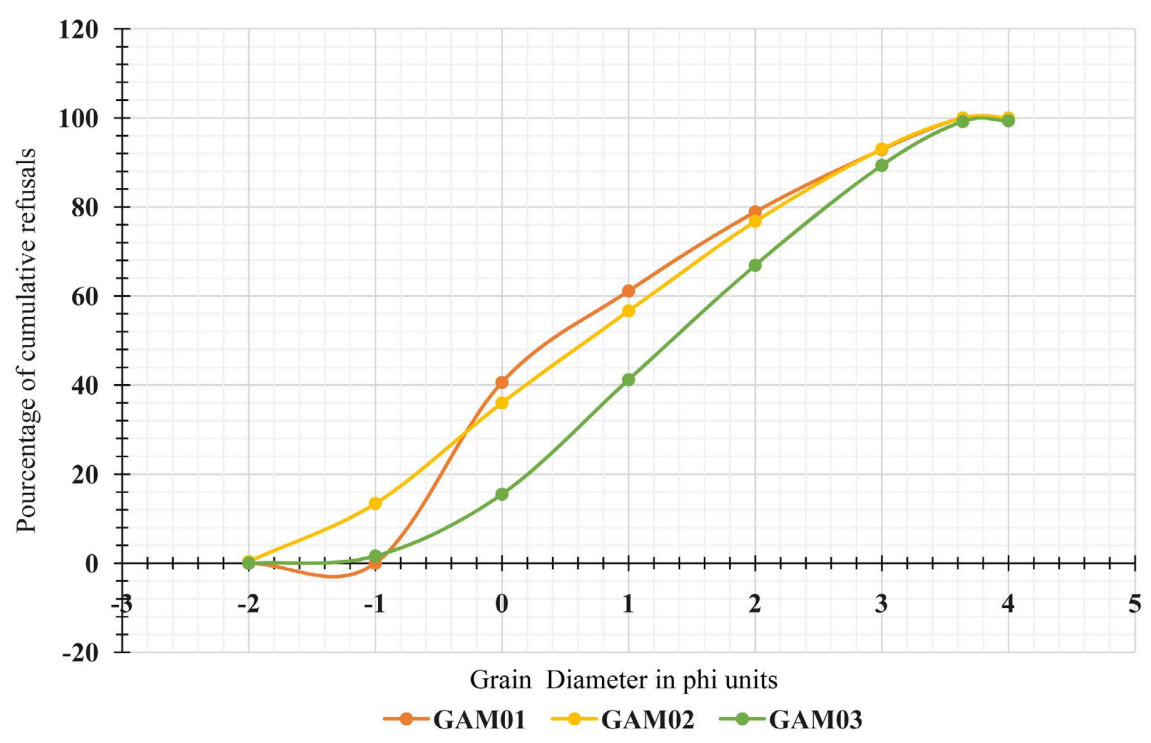

(a)

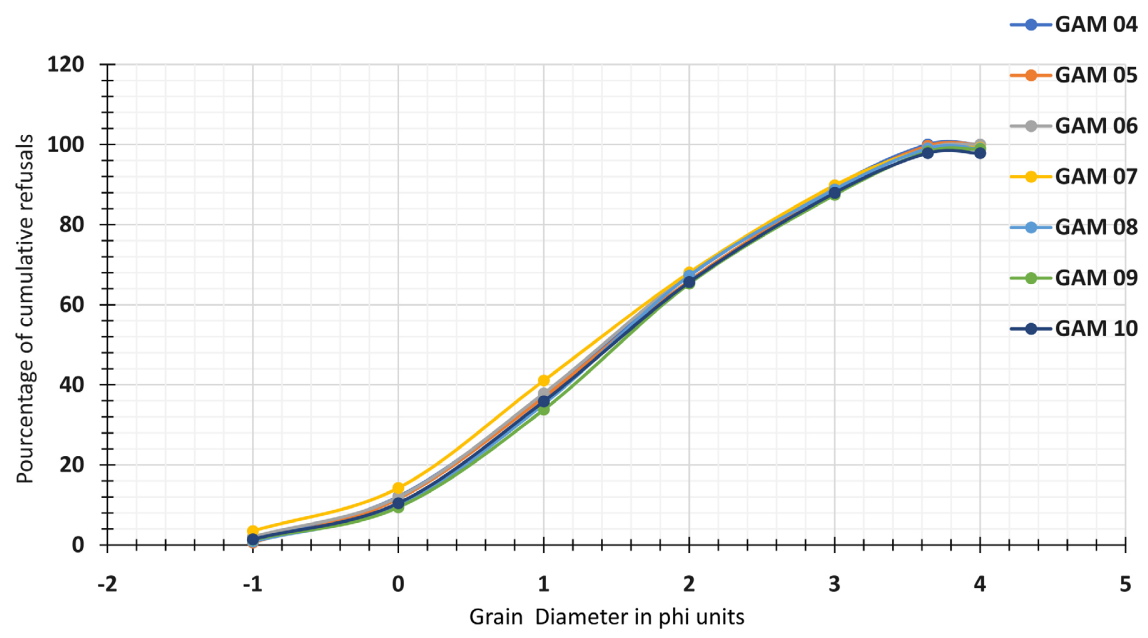

(b)

Figure 6. Cumulative granulometric curves of the yellow formation in the Mossendjo area.

The log of the outcrop of the yellow formation of the train station has two granulometric facies. At the base, very asymmetrical to fine gravelly sands and poorly graded. The second facies is made up of almost symmetrical medium sands, poorly graded (Table 3 ).

\section{Transport and sedimentation mode}

The projection of the data on Passega's diagram [22] (Figure 7) shows that almost all the sands from the hospital borehole occupy the QP portion (Figure $7(a))$. This translates into graduated suspension transport. The sands from the drilling of the train station (Figure 7(b)) show modes of transport represented by the branches $\mathrm{PO}$ and $\mathrm{ON}$ for the lower unit and QP for the upper unit. Thus, the transport of these sands is done by rolling with graduated suspension. In addition, the sampling of the outcrop of the train station (Figure $7(\mathrm{c})$ ) shows a 
Table 1. Granulometric characteristics of the samples from the hospital borehole.

\begin{tabular}{|c|c|c|c|c|c|}
\hline & Samples & Mean & $\begin{array}{l}\text { Standard } \\
\text { deviation }\end{array}$ & asymmetry & Description \\
\hline \multirow{2}{*}{$\begin{array}{l}\text { Upper } \\
\text { unit }\end{array}$} & MOS-H03 & 2.52 & 0.93 & -0.39 & $\begin{array}{l}\text { Fine sands, moderately graded, } \\
\text { asymmetry towards coarse }\end{array}$ \\
\hline & MOS-H04 & 1.9 & 1.1 & -0.08 & $\begin{array}{l}\text { Medium sands poorly graded } \\
\text { symmetrical }\end{array}$ \\
\hline \multirow{8}{*}{$\begin{array}{l}\text { Lower } \\
\text { unit }\end{array}$} & MOS-H05 & -0.48 & 1.06 & -0.12 & $\begin{array}{l}\text { Coarse sands and gravels, poorly } \\
\text { graded asymmetric to coarse }\end{array}$ \\
\hline & MOS-H06 & 1.06 & 0.65 & 0.06 & $\begin{array}{l}\text { Medium sands, fairly well graded } \\
\text { almost asymmetric }\end{array}$ \\
\hline & MOS-H07 & 0.57 & 0.87 & 0.12 & $\begin{array}{l}\text { Coarse sands and gravels, } \\
\text { very well classified asymmetry } \\
\text { towards the fin }\end{array}$ \\
\hline & MOS-H08 & 1.01 & 1.02 & -0.15 & $\begin{array}{l}\text { Medium sands, poorly graded } \\
\text { asymmetric towards coarse }\end{array}$ \\
\hline & MOS-H09 & 1.67 & 0.54 & 0.25 & $\begin{array}{l}\text { Medium sands, fairly well classified } \\
\text { asymmetry towards the ends }\end{array}$ \\
\hline & MOS-H10 & 0.29 & 0.76 & 0 & $\begin{array}{l}\text { Coarse sands and gravels, } \\
\text { moderately graded almost } \\
\text { symmetrical }\end{array}$ \\
\hline & MOS-H11 & 0.85 & 0.6 & 0.27 & $\begin{array}{l}\text { Coarse sands and gravels, } \\
\text { fairly well classified asymmetry } \\
\text { towards the fine }\end{array}$ \\
\hline & MOS-H12 & 0.77 & 0.7 & 0.11 & $\begin{array}{l}\text { Coarse sands and gravels, } \\
\text { very well classified, asymmetry } \\
\text { towards the fine }\end{array}$ \\
\hline
\end{tabular}

Table 2. Granulometric characteristics of the samples from the train station borehole.

\begin{tabular}{ccccl} 
Samples & Mean & $\begin{array}{l}\text { Standard } \\
\text { deviation }\end{array}$ & asymmetry & \multicolumn{1}{c}{ Description } \\
\hline GA-3 & 1.72 & 0.67 & 0.16 & $\begin{array}{l}\text { Medium sands, fairly well classified with } \\
\text { asymmetry towards the ends }\end{array}$ \\
GA-4 & 1.64 & 0.52 & 0.21 & $\begin{array}{l}\text { Medium sands, fairly well classified with } \\
\text { asymmetry towards the ends }\end{array}$ \\
GA-5 & 1.1 & 0.62 & -0.02 & $\begin{array}{l}\text { Medium sands, fairly well graded almost } \\
\text { symmetrical }\end{array}$ \\
GA-6 & 0.5 & 0.6 & 0.26 & $\begin{array}{l}\text { Coarse sands and gravels, fairly well } \\
\text { classified with asymmetry towards the fine } \\
\text { GA-7 }\end{array}$ \\
0.23 & 0.87 & 0.11 & $\begin{array}{l}\text { Coarse sands and gravels, moderately } \\
\text { graded with asymmetry towards the fine }\end{array}$ \\
GA-8 & 1.4 & 0.75 & $\begin{array}{l}\text { Medium sands, moderately graded almost } \\
\text { symmetrical }\end{array}$ \\
\hline
\end{tabular}

mode of transport represented by the QP and PO branches. This indicates a transport by graduated suspension and rolling. 


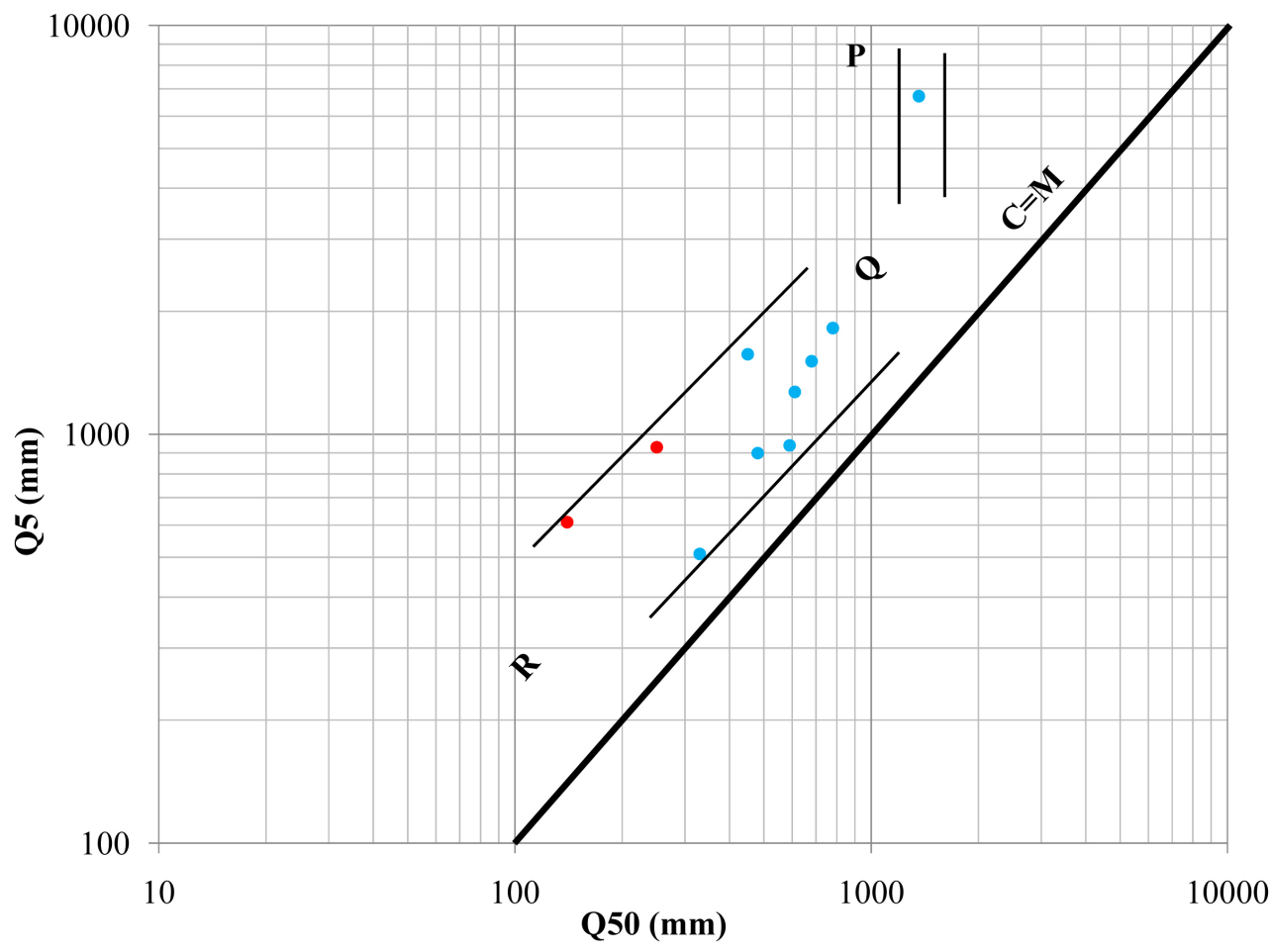
Légend:
$\bullet \bullet$
Upper unit
Lower unit

(a)

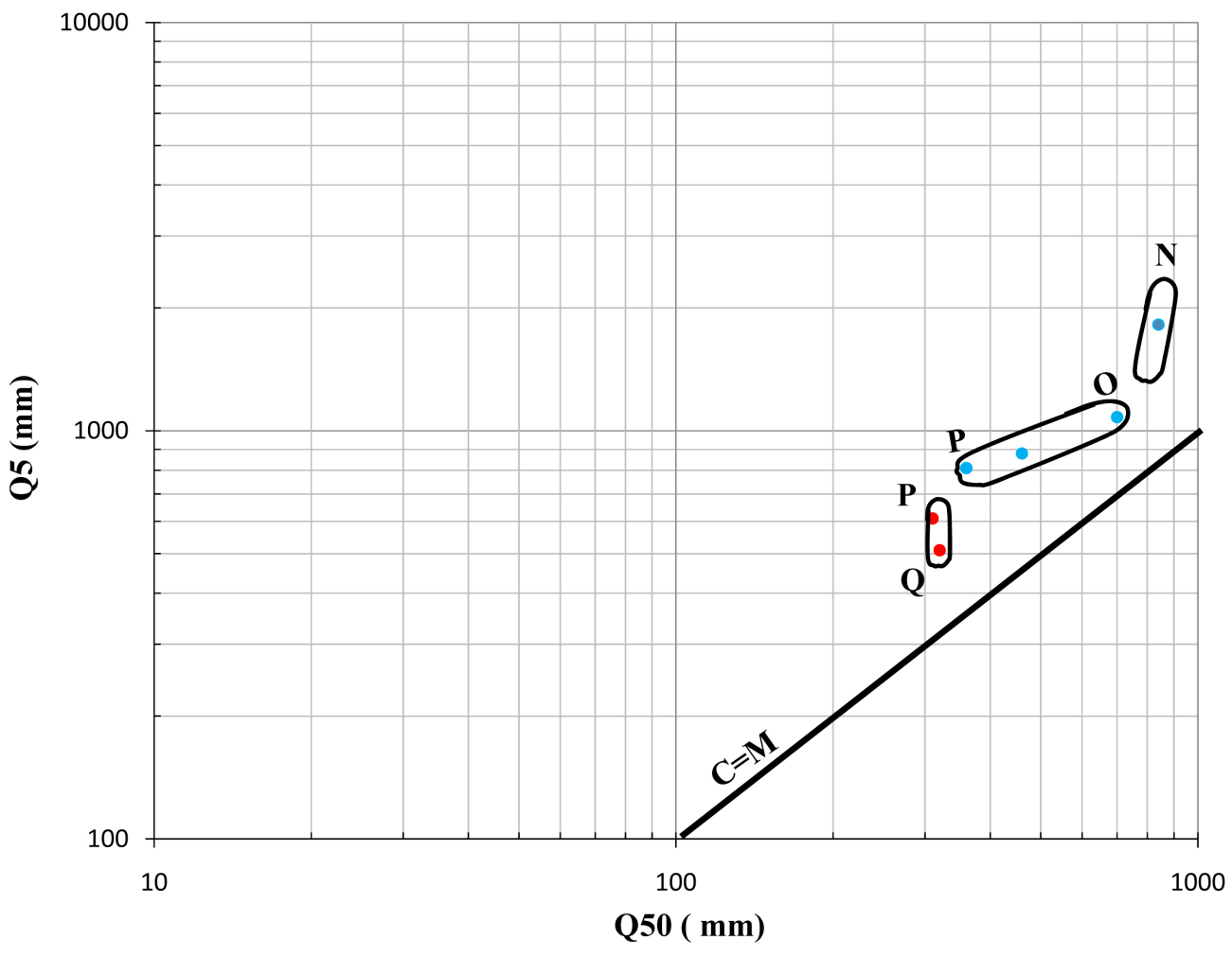

Légend: $\quad$ Upper unit $\quad$

(b) 


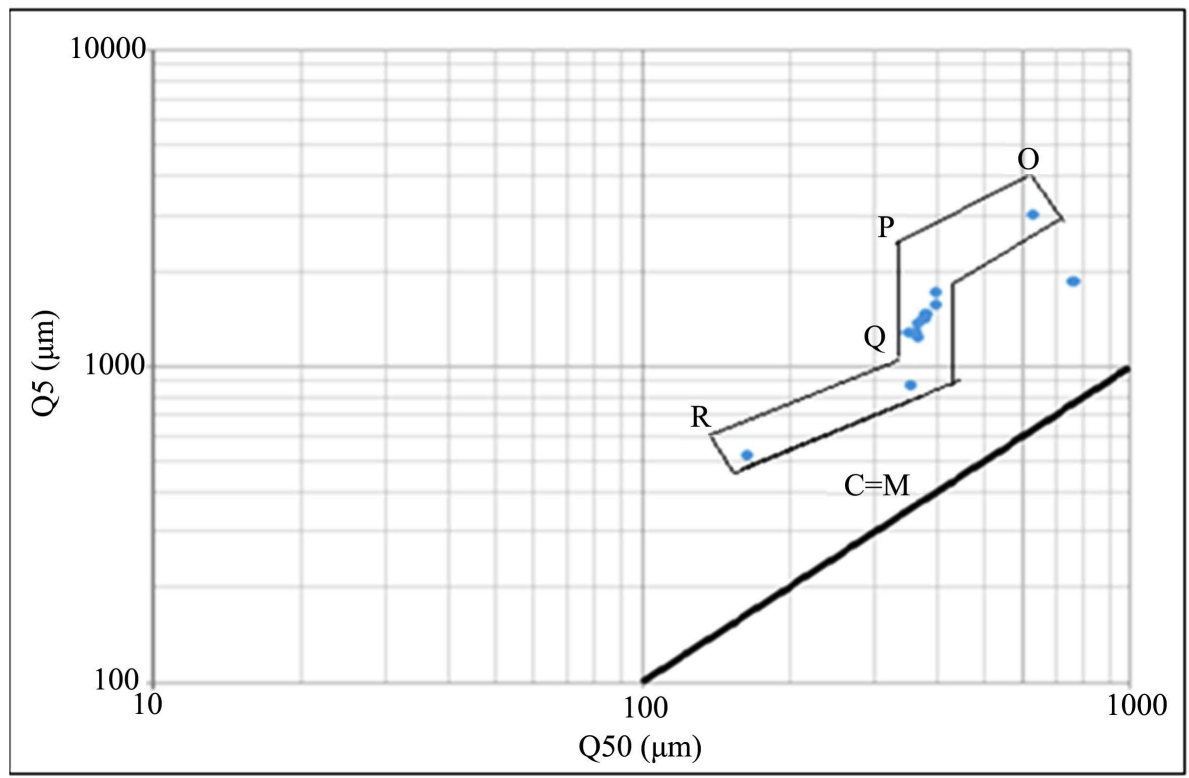

(c)

Figure 7. Passega diagrams of the survey samples. (a) Hospital; (b) Train station; and (c) Yellow formation.

Table 3. Granulometric characteristics of the samples of the yellow formation.

\begin{tabular}{|c|c|c|c|c|}
\hline Samples & Mean & $\begin{array}{l}\text { Standard } \\
\text { deviation }\end{array}$ & asymmetry & Description \\
\hline GAM 01 & 0.7 & 1.75 & 4.37 & $\begin{array}{l}\text { Coarse sands and gravels very } \\
\text { poorly graded } \\
\text { asymmetric towards the fine }\end{array}$ \\
\hline GAM 02 & 0.79 & 1.71 & 3.23 & $\begin{array}{l}\text { Coarse sands and gravels poorly } \\
\text { graded asymmetric towards the fine }\end{array}$ \\
\hline GAM 03 & 1.39 & 0.69 & -0.05 & $\begin{array}{l}\text { Medium sands, moderately graded } \\
\text { almost symmetrical }\end{array}$ \\
\hline GAM 04 & 1.32 & 0.75 & -0.42 & $\begin{array}{l}\text { Medium sands, moderately } \\
\text { classified symmetrical }\end{array}$ \\
\hline GAM 05 & 1.44 & 0.81 & 0.05 & $\begin{array}{l}\text { Coarse sands and gravels, } \\
\text { moderately graded } \\
\text { with asymmetry towards the fine }\end{array}$ \\
\hline GAM 06 & 1.76 & 0.70 & 0.06 & $\begin{array}{l}\text { Medium sands, moderately } \\
\text { graded almost symmetrical }\end{array}$ \\
\hline GAM 07 & 1.4 & 0.73 & 0.09 & $\begin{array}{l}\text { Medium sands, moderately } \\
\text { graded almost symmetrical }\end{array}$ \\
\hline GAM 08 & 1.5 & 0.68 & 0.09 & $\begin{array}{l}\text { Medium sands, moderately } \\
\text { graded almost symmetrical }\end{array}$ \\
\hline GAM 09 & 1.55 & 0.76 & 0.04 & $\begin{array}{l}\text { Medium sands, moderately } \\
\text { graded almost symmetrical }\end{array}$ \\
\hline GAM 10 & 1.51 & 0.87 & -0.07 & $\begin{array}{l}\text { Medium sands, moderately } \\
\text { graded almost symmetrical }\end{array}$ \\
\hline GAM 11 & 1.52 & 0.81 & 0.34 & $\begin{array}{l}\text { Medium sands, moderately } \\
\text { graded almost symmetrical }\end{array}$ \\
\hline
\end{tabular}


The diagram of [23] (Figure 8), shows that the sands of the upper unit of the hospital borehole (Figure 8(a)) were deposited by free accumulation, part of the sands of the lower unit (MOS-H06, MOS-H08, MOS-H09, MOS-H11 and MOS-H12) and the sands of the station outcrop (Figure $8(c)$ ) sedimented by free accumulation and for others (MOS-H 05, MOS-H 07 and MOS-H 10), by free accumulation close to the forced deposit. In addition, the majority of the sand samples from the borehole of the railway station were deposited by free accumulation except the coarse level 2 sample (GA-7) which is in the domain of free accumulation near the forced deposit (Figure 8(b)).

By plotting the values of the median as a function of those of the standard deviation in the diagram of [24], we notice that the cloud of points is located in the zone of sands of fluvial origin (Figure 9).

\subsubsection{Morphoscopic and Mineralogical Analyses \\ Morphoscopic analysis}

The morphoscopic study of the quartz grains carried out on the $250 \mu \mathrm{m}, 500$ $\mu \mathrm{m}$ and $1000 \mu \mathrm{m}$ fractions reveals the presence of a high percentage of angular and shiny grains in the samples from the hospital and station boreholes. The quartz grains of the yellow formation are essentially angular and shiny. Some of them have micro fractures that appear parallel, sometimes intertwined (Figure 10).

\section{Mineralogy of clays}

The analysis of the mineralogical characteristics by X-ray diffraction of the clayey levels of the formations in the upper unit of the log of the Mossendjo hospital (Figure 11 and Table 4) indicates that the sediments analyzed present a mineralogical sequence consisting of clayey and non-clayey minerals.

\subsubsection{Chemical Analysis}

Figure 12(a) and Figure 12(b) show the variations in carbon, nitrogen, organic

Table 4. Mineralogical procession and mineral contents of the upper unit.

\begin{tabular}{ll}
\hline Samples & \multicolumn{1}{c}{ Minerals } \\
\hline & 1. Quartz (10\%) \\
& 2. Kaolinite (57\%) \\
& 3. Muscovite (Illite) (20\%) \\
& 4. Montmorillonite (Smectite) (10\%) \\
& 5. Trace Hematite (1\%) \\
& 1. Quartz (30\%) \\
& 2. Kaolinite (42\%) \\
& 3. Muscovite (19\%) \\
& 4. hématite (4\%) \\
& 5. Gibbsite (3\%) \\
& 6. Trace d'anatase (1\%)
\end{tabular}




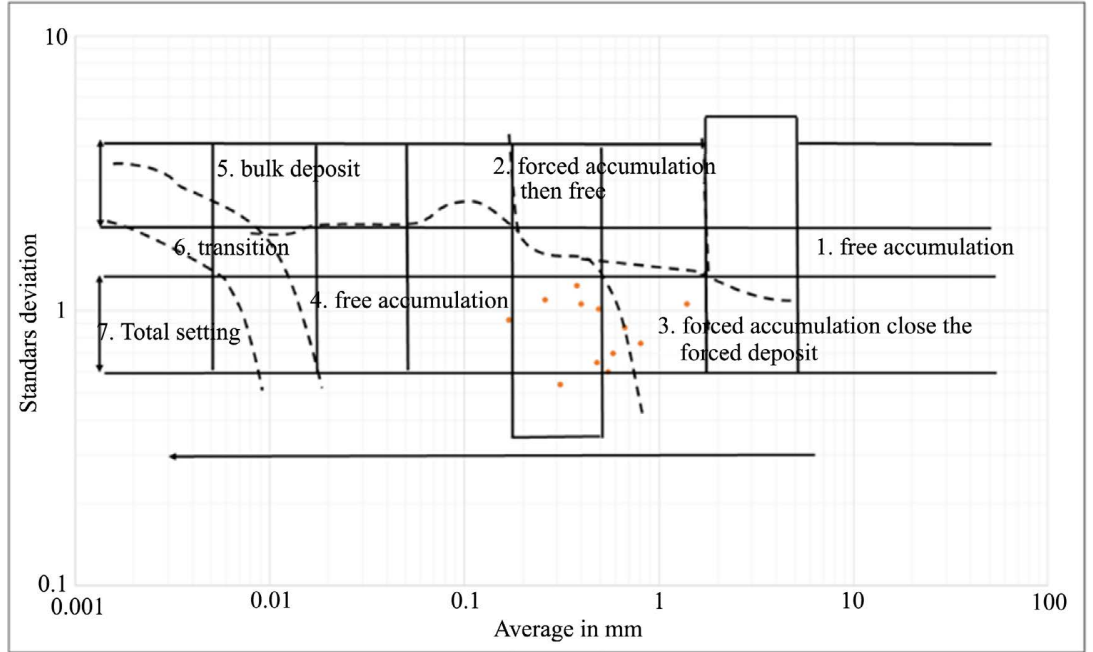

(a)

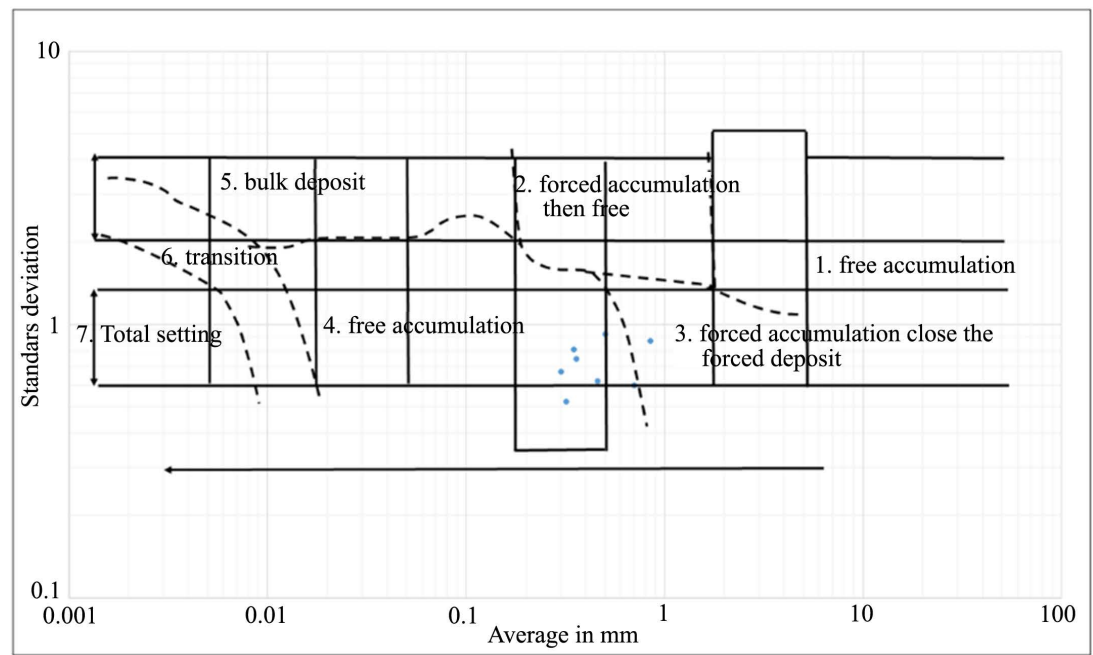

(b)

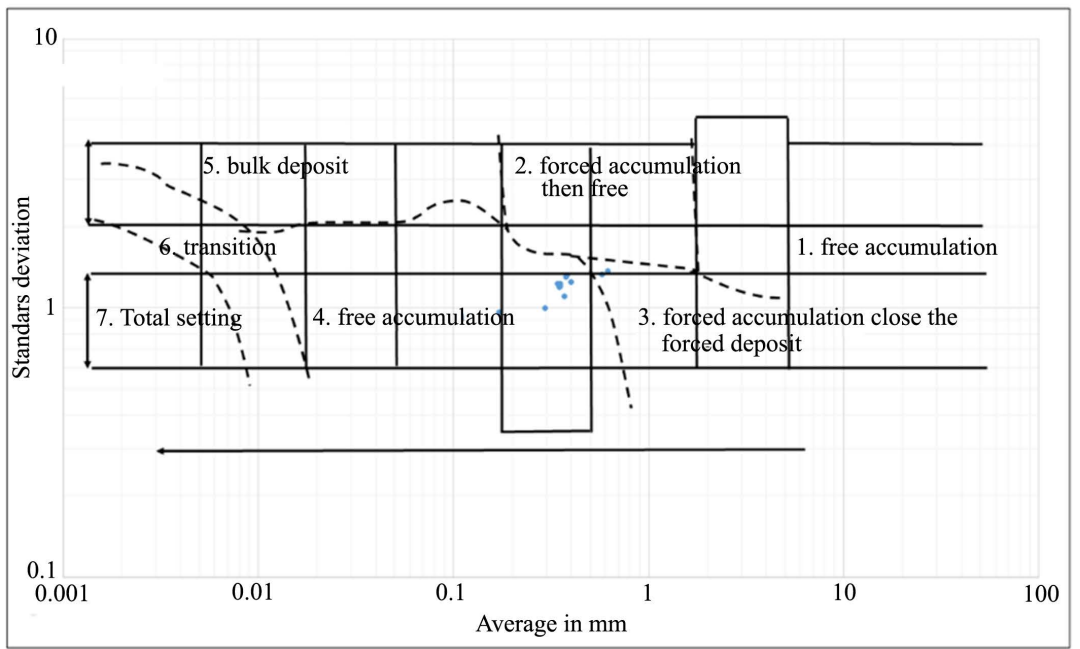

(c)

Figure 8. Losson's diagram (2006) of the formations of the studied sites. (a) Hospital; (b) Railway station; and (c) Yellow formation. 


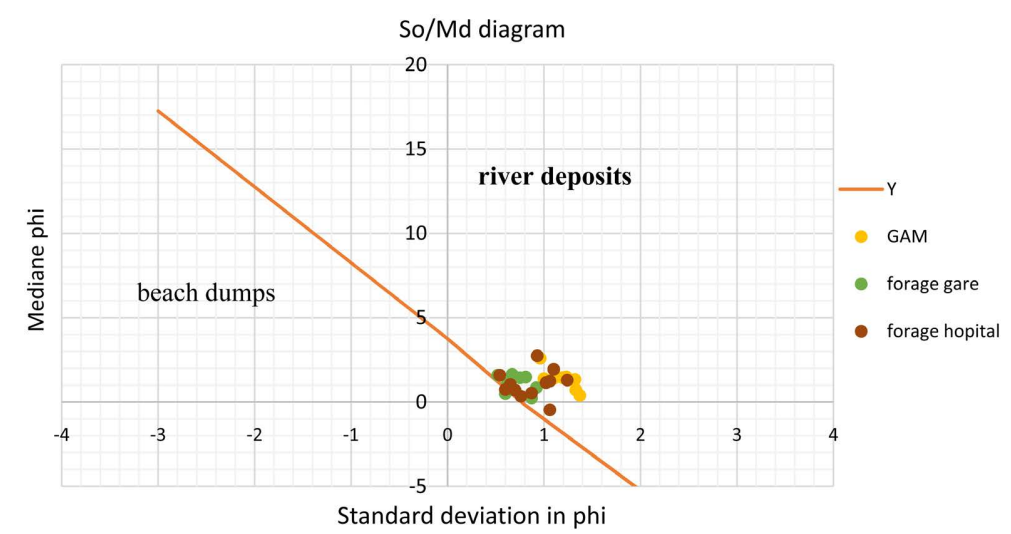

Figure 9. Miola and Weiser (1958) diagram applied to the Mossendjo samples.
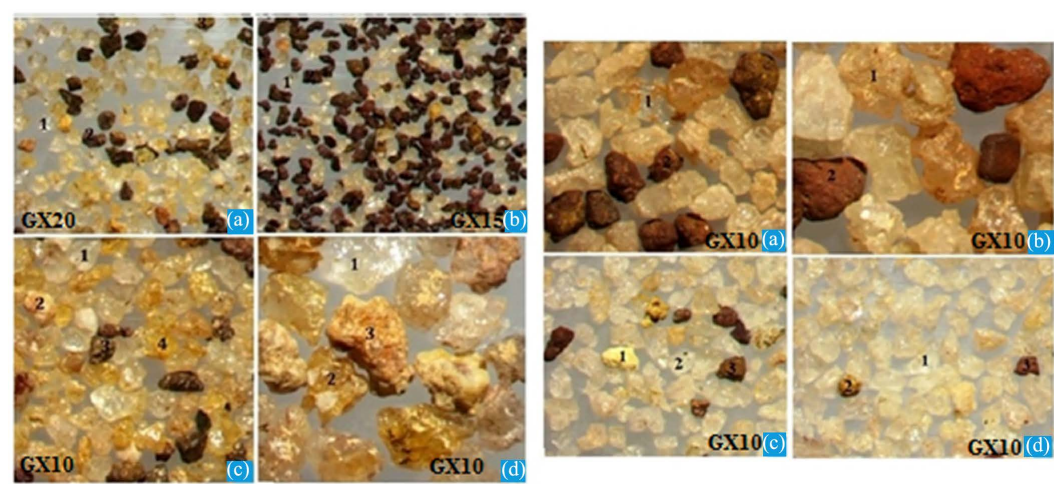

Figure 10. Morphoscopic characteristics of sand grains in the Mossendjo area. Legend: (a) and (b): Sample from level 7, at 1 and $2 \mathrm{~mm}$ respectively. 1-fragment of shiny angular quartzite; 2 -a grain of laterite; (c): Sample from level 5, at $0.500 \mathrm{~mm}$ : 1 -fragment of quartzite, 2-crystallization of magnetite on the surface of the quartz grain; 3-grain of laterite; (d): Sample of levels 3 and 4 respectively with: 1, 2 and 4 the quartzite debris with several colors; 3-grain of laterite. (a): Sample from level 6, $0.5 \mathrm{~mm}$ with: 1-piece of shiny angular quartzite; 2 -a grain of laterite. (b): Sample Level 5, at $0.250 \mathrm{~mm}$ where the laterite grains dominate the quartzite fragments: 1 -shiny angular quartzite debris; 2 -grain of laterite. (c): Sample from level 3, at $0.5 \mathrm{~mm}$ : 1, 4-fragment of shiny angular quartzite, 2-feldspar; 3-laterite grain. (d): Sample from level 2 to $2 \mathrm{~mm}$ with: 1-shiny angular quartzite debris, 2-quartz sandstone with silica cement, 3 -quartz sandstone with iron oxide cement.

matter, and carbon-to-nitrogen ratios of samples from the hospital and station boreholes.

The variations in nitrogen content along the log are very small; the maximum value obtained is $0.05 \%$. The vertical evolution of carbon, organic matter and carbon-to-nitrogen ratio along the log of site 1 show two phases. The first phase, corresponding to the upper unit of the log, has maximum carbon and organic matter values of 1.4 and 2.41, respectively. The second phase presents an almost constant evolution with very low carbon and organic matter contents with a maximum value of $0.07 \%$ and $0.12 \%$ respectively (Figure $12(\mathrm{a})$ ). Along the log of the borehole at Mossendjo station, the nitrogen content fluctuates between $0.01 \%$ and $0.04 \%$. It varies from base to summit along the lithological log (Figure 12(b)). The organic carbon content varies between 0.08 and 1.05 (Figure 12(b)). 


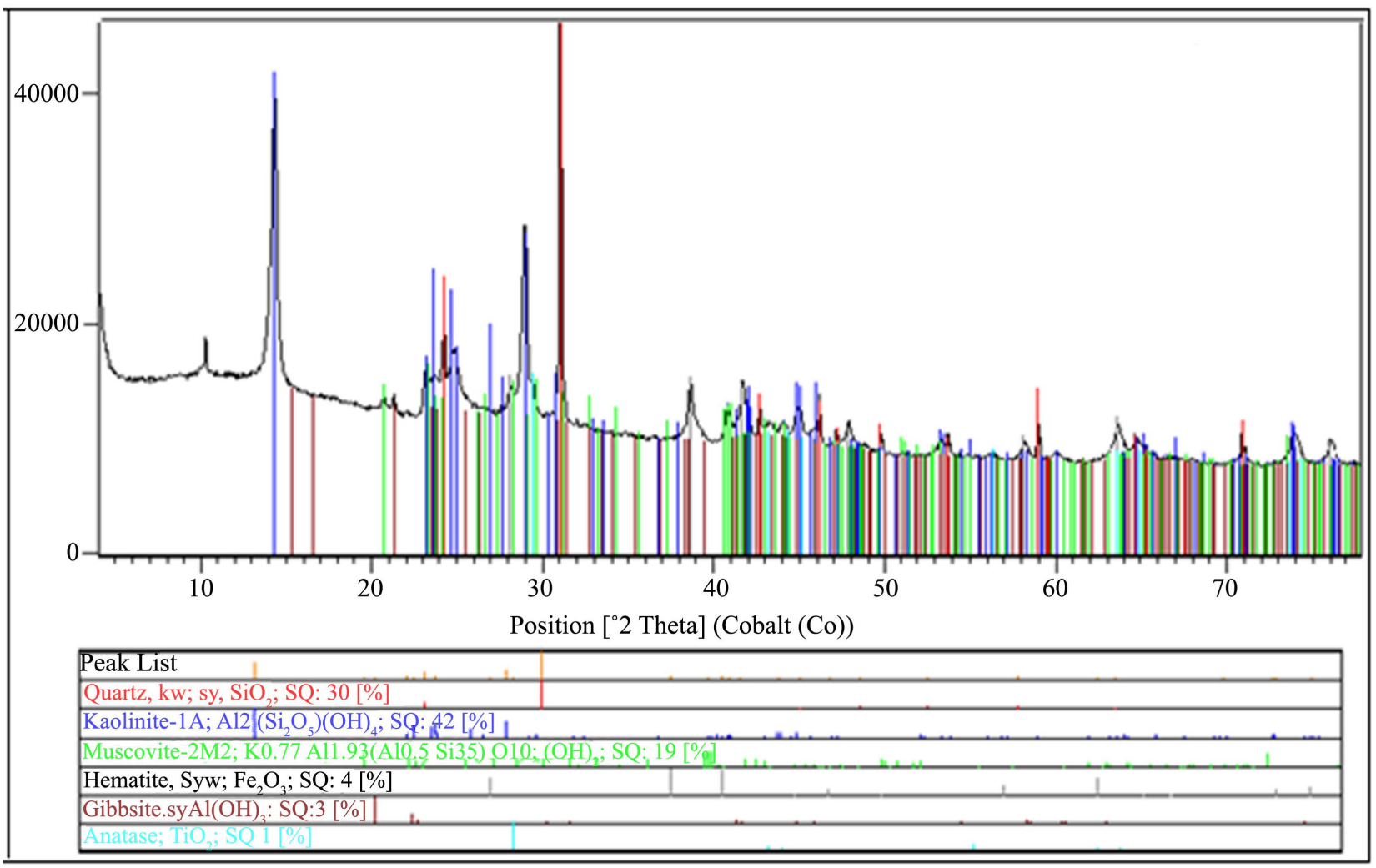

(a)

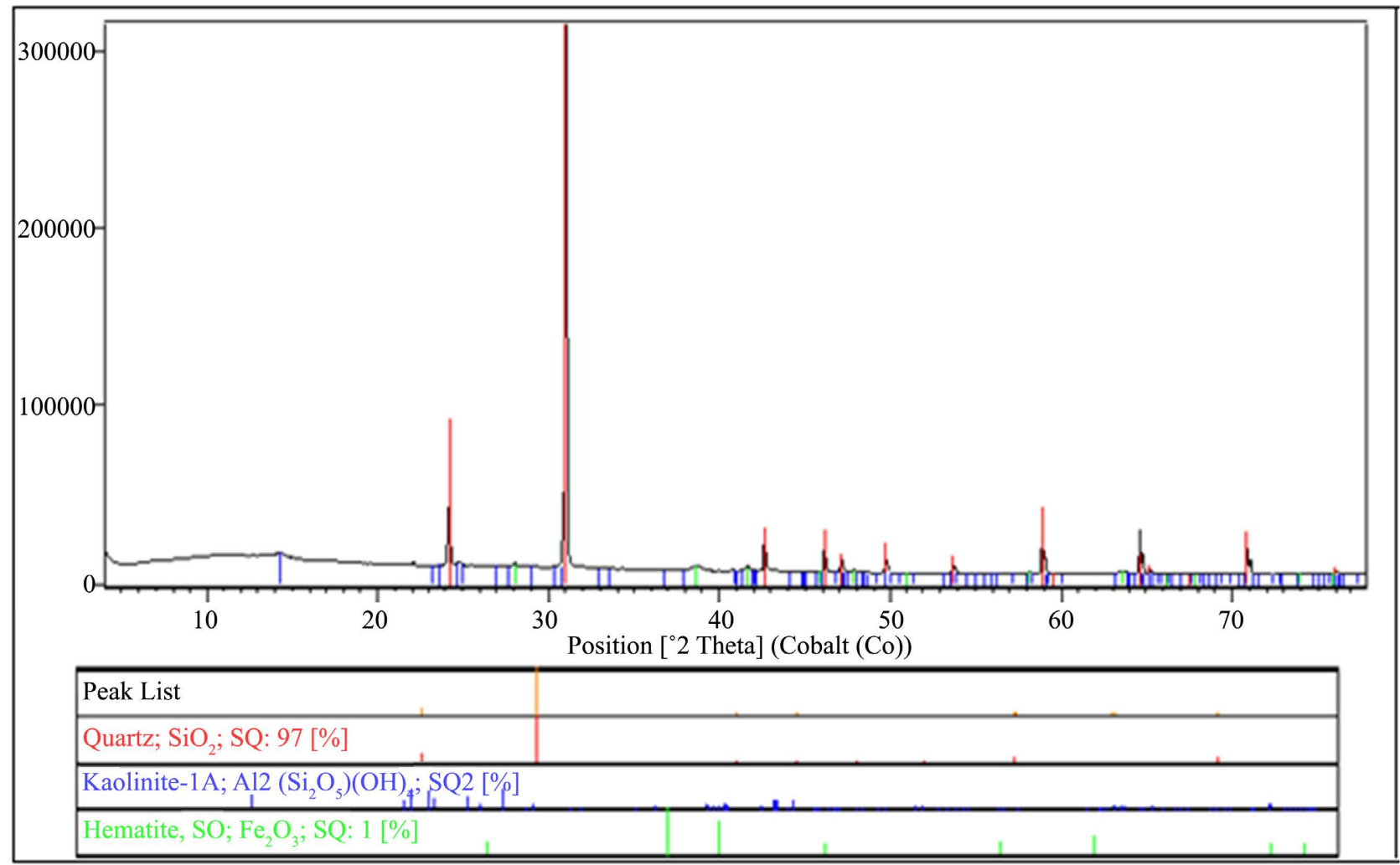

(b)

Figure 11. X-ray diffractograms. (a) Plastic clay of the MOSH03 level; (b) Clayey-sandy silt of the MOSHO4 level. 


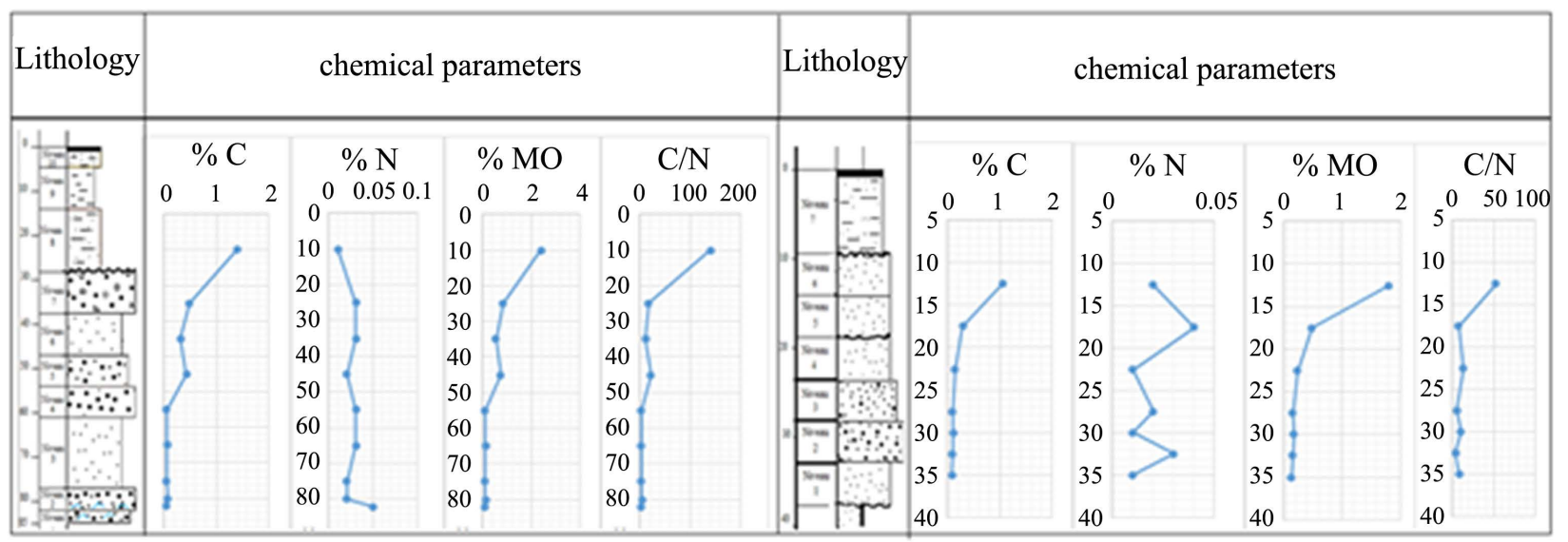

(a) (b)

Figure 12. (a) Evolution of nitrogen and carbon contents, $\mathrm{C} / \mathrm{N}$ ratio and organic matter in the log of the hospital borehole. (b) Changes in nitrogen and carbon content, $\mathrm{C} / \mathrm{N}$ ratio, and organic matter in the station log.

Along the lithologic log, the $\mathrm{C} / \mathrm{N}$ ratio reaches its maximum at 52.50. Organic matter exhibits a similar evolution to carbon.

The variations in organic carbon, nitrogen and organic matter contents along the log are very small. They vary from $0.26 \%$ to $1.26 \%$ for carbon, from $0.02 \%$ to $0.09 \%$ for nitrogen and from $0.44 \%$ to $2.17 \%$ for organic matter. The carbon-nitrogen ratio shows slight fluctuations, sometimes upwards, sometimes downwards (Figure 13).

\section{Interpretation and Discussion}

The sequential analysis of the logs from the boreholes of the hospital and the Mossendjo train station shows the existence of a succession of sequences formed at the base of coarse sands, or even gravel, topped by a thick level of medium sands (Figure 2 and Figure 3). The hospital log shows the existence of three sequences, the third of which is truncated since it only shows the coarse part. Analysis of the sequences presented by these formations shows that they are of channel types as described by [25].

The results of the laboratory analysis confirm the field observations. Indeed, from the granulometric analysis of the sand deposits from the hospital borehole, it appears that the cumulative curves of the sands of the upper and lower units (Figure 5(a), Figure 5(b)) are sigmoidal with a regular and spreading slope. This shows that this deposition occurred as a result of the variation in the competence of the carrier current, as indicated by [19] and [26]. The sands of the lower unit are coarse and moderately graded. This result is confirmed by the coarse sand contents oscillating between $70.83 \%$ and $93.16 \%$ (Figure 14). The upper unit is characterized by an increase in pelite contents varying between $64.35 \%$ and $88.49 \%$. The sands in this unit are fine to medium, moderately to poorly graded (Table 1 ). The mineralogy of the upper unit clays revealed that they consist predominantly of kaolinite. This Kaolin clay is found associated with gibbsite, muscovite, quartz and hematite. These results are comparable to 


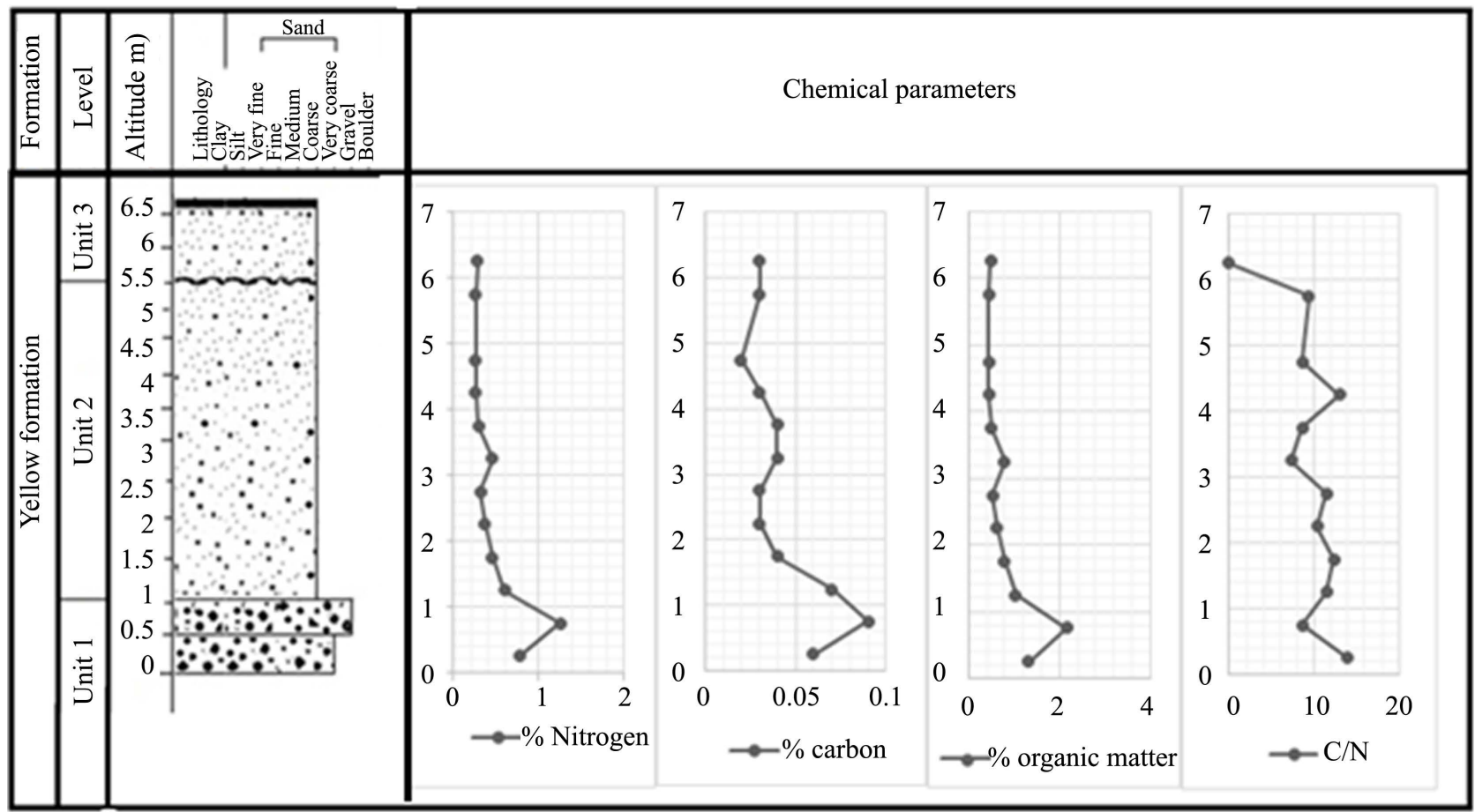

Figure 13. Evolution of nitrogen and carbon contents, of the $\mathrm{C} / \mathrm{N}$ ratio and of the organic matter of the yellow formation.

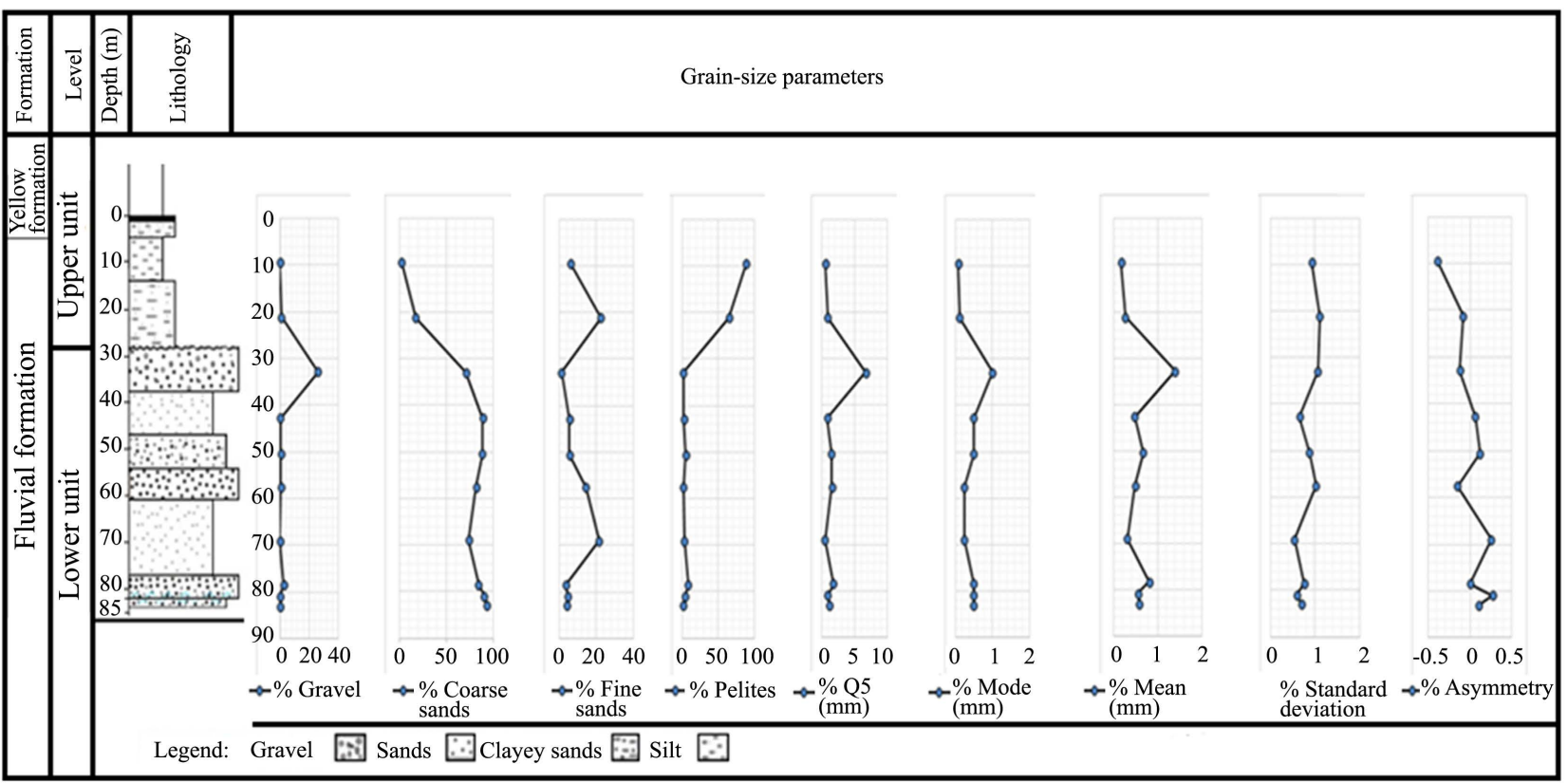

Figure 14. Evolution of the granulometric parameters along the log of the hospital drilling.

those of [6] and [8] who showed that kaolinite is the dominant mineral in the surface formations in the Chaillu area. The high clay contents in this unit (Table 4) show that the deposits of the upper unit took place in a slightly agitated medium, at medium energy. These deposits are allocated to the phase of clogging of the channel. This result is confirmed by the high value of the $\mathrm{C} / \mathrm{N}$ ratio (Figure 12). 
The cumulative sands from the station borehole show a sigmoidal shape, with a regular slope, moderately straightened (Figure 5(c), Figure 5(d)). The sands of this hole are distinguished by fluctuations in sediment stocks. Thus, coarse sands range from $63.47 \%$ and $82.10 \%$, fine sands from $5.38 \%$ and $27.39 \%$ and pelites from $9.13 \%$ and $15.17 \%$ (Figure 15). The sands in this unit are coarse to medium, moderately graded (Table 2). The Q5 fractile is variable, showing a slight increase in the basal unit (Figure 15). This behavior suggests variable dynamics of the velocity of the transporter, confirmed by the sigmoidal shape of the cumulative curves.

Morphoscopic analysis of quartz grains from hospital and station boreholes revealed an abundance of angular and shiny grains (Figure 10). The abundance of this family of grains indicates an aquatic mode of transport [27] [28] [29] [30]. This result shows the influence of an aquatic transport corresponding in the context of this study to fluvial dynamics.

The lithological analysis of the yellow formation shows a sandy-gravelly basal level at the outcrop, the whole surmounted by coarse to medium sands apparently homogeneous, poor in clay and without apparent structure. This arrangement is similar to that described by [11] [13] [31] in Gabon, and [12] [14] [32] in Congo; in D.R. Congo by [33] [34] [35], and in Cameroon by [36]. For these authors, this arrangement corresponds to the cover formation.

The results of the particle size study show that the cumulative particle size curves of the sands of the yellow formation present a sigmoidal shape, with regular slopes, moderately straightened (Figure 6). The work carried out by [18] and [37], demonstrate that this sigmoidal shape characterizes moderately classified deposits, which is confirmed by the values of the standard deviation oscillating around 0.6 in phi unit. The proportions in pelites are relatively low, ranging between $0.1 \%$ and $9.82 \%$, in fine sands between $17.25 \%$ and $33.52 \%$, in coarse sands between $16.13 \%$ and $61.14 \%$ finally in gravels between $0 \%$ and $13.07 \%$.

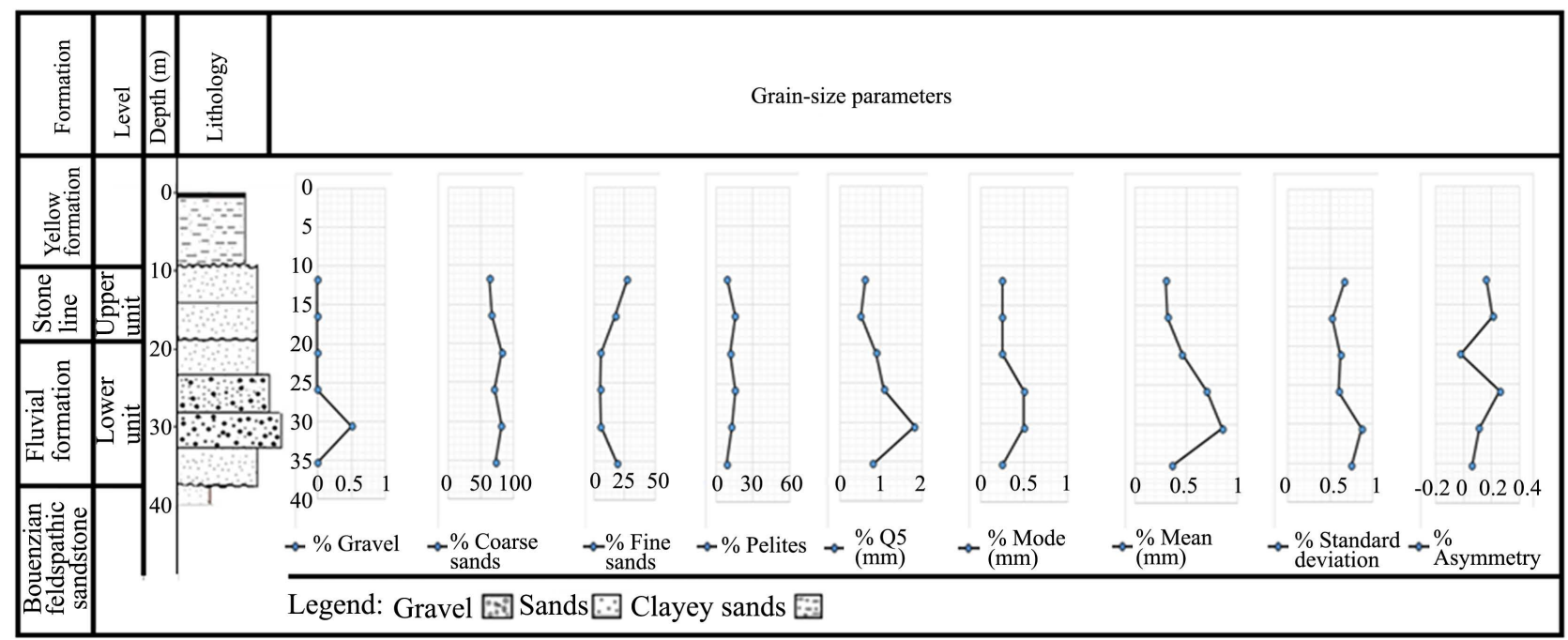

Figure 15. Vertical evolution of the granulometric facies as a function of the depth of the log of the train station borehole. 
Morphoscopic study of the quartz grains (Figure 10) reveals a dominance of shiny angular grains. This characteristic indicates that these grains underwent a short transport in the aquatic environment. The relatively low levels of organic matter (Figure 12) suggest that these deposits were deposited in a highly hydrodynamic environment which, in the case of a river system, would correspond to a channel.

The Passega's diagram (Figure 7) shows that the sediments and sands in the analyzed boreholes have two modes of transport: transport by bottom haulage and transport by rolling. Concerning the mode of deposition, the Losson diagram (Figure 8) shows two modes of deposition, namely free accumulation for the majority of the sands and free accumulation close to the forced deposition. This result shows that the current built up these deposits, which confirms the channel type fluvial system as described by the lithological analysis.

Despite the similarities between the outcrop of the yellow formation deposits and the overburden formation described by [11] [13] [14], the general synthesis of the granulometric, mineralogical and chemical analysis of the yellow formation deposits in the Mossendjo sector has enabled us to highlight a channel-type fluvial system.

The lithostratigraphic correlation of the boreholes carried out at the train station and the hospital indicates that the levels observed are overcome by the yellow formation. At the hospital, in the silt-clay level of the upper unit, mineralogical analyses (Table 4) show the presence of Gibbsite and laterite gravel, which allows us to highlight the existence of an ancient laterite cuirass which has been dismantled and whose pelitic fraction constitutes this deposit. This nature allows us to justify the existence of a gullying paleosurface that would delimit the two units and justifies the truncated nature of the third sequence of the lower unit. The truncated character of the basic formation (Figure 2) shows a superimposition of fluvial phases which are not contemporary and but diachronous.

The general synthesis of the granulometric, mineralogical, morphoscopic and chemical analysis of the boreholes in the Mossendjo sector has enabled us to highlight three major paleoenvironmental phases: the first, the oldest, is characterised by a channel type fluvial system marked by the deposits from the hospital and station borehole; the second, which is alluvial, corresponds to the clogging of the channel. These two alluvial phases are surmounted by a third, fluvial, channel type phase, the end of which is marked by the settlement of the yellow formation.

Most pedological work carried out in the Chaillu sector by [1] [4] [5] [6] [7] [8] show that the superficial formations in this zone are alterites. These authors have highlighted three levels in these formations: The superficial horizon consisting only of loose and fine textured materials; characterized by its great homogeneity of texture, structure and color. The color of the shallow horizon varies from yellow ocher to red ocher. This is characteristic of ferralitic soils. The constituent elements do not vary significantly over the entire thickness. In the gravel horizon (stone line) and the weathering horizon or $\mathrm{C}$ horizon, different 
soil horizons are differentiated in a material that seems to have evolved in place. It emerges from this study that in the Mossendjo sector, the superficial formations are the product of transport in a fluvial environment and that the alteration profiles described by [5] and observed in the Chaillu area do not outcrop everywhere.

\section{Conclusions}

Sedimentological, petrographic, geochemical and morphoscopic analyzes of the Mossendjo deposits obtained by drilling have enabled us to highlight a channel-type fluvial system. In fact, the shiny and polished character of the grains constituting these deposits allows us to conclude that they have settled in an aquatic system. These deposits are organized in successive positive channel-like sequences, but the top sequence has been truncated since it is represented only by its gravelly basal level. The yellow formation which outcrops throughout the Mossendjo area rests in gully unconformity on this underlying level. This outcrop has the same characteristics as those described by [12] [14] in Congo and [13] in Gabon who attributed this formation to the superficial formation.

But the synthesis of field and laboratory analyzes allowed us to highlight a channel-type fluvial system identical to that described in the lower levels except that the latter rests in gully unconformity on the first. Thus, we can conclude that there are two channel-type fluvial episodes that are diachronous. It, therefore, appears that the yellow formation which outcrops over much of West Central Africa was not established everywhere by the same sedimentary dynamics. It is believed to be of fluvial origin in the Chaillu massif. This conclusion is in agreement with previous data which recognizes the existence of forest refugia during the arid phase ca 3000 years BP [38] [39] and to which the windy character of the superficial formation is attributed. However, to consolidate these results, it is recommended to continue these analyzes in other regions of the Congo such as in the West Cuvette, geologically very close to Chaillu.

\section{Acknowledgements}

The authors thank the Centre de Recherches Géologiques et Minières (CRGM) and its Director General for sedimentological and mineralogical analyses. We also thank the Department of Geosciences of the University of Warsaw for the mineralogical analyses by DRX.

\section{Conflicts of Interest}

The authors declare no conflicts of interest regarding the publication of this paper.

\section{References}

[1] Laporte, G. (1962) Reconnaissance pédologique le long de la voie ferrée COMILOG (République du Congo). Centre ORSTOM, Brazzaville, MC119, 149 p. 
[2] Brugiere, J.M. (1962) Soil Knowledge in the Mayombe, the Niari Valley and the Chaillu Massif, Their Development. Office for Scientific and Technical Research in Overseas Territories, Institut de recherches scientifiques du Congo, Brazzaville, MC118, 35 p.

[3] Dadet, P. (1969) Notice explicative de la carte geologique de la Pepublique du Congo Brazzaville au 1/500 000 (zonne comprise entre les parallèles $2^{\circ}$ et $5^{\circ} \mathrm{Sud}$ ). Bureau de Recherches Géologiques et Minières, Paris, 107 p.

[4] Novikoff. A. (1969) Alteration of Rocks in the Chaillu Massif (Republic of Congo). Silicification of Gibbsite. Study of the Alteration Facies Rich in Kaolinite, Containing Gibbsite Balls. Office for Overseas Scientific and Technical Research, Brazzaville, MC 159, $53 \mathrm{p}$.

[5] Novikoff, A. (1970) The Alteration of Rocks in the Chaillu massif. Etude des horizons superficiels, leurs relations avec les horizons d'altération, Office for Overseas Scientific and Technical Research, Brazzaville, MC 164, 65 p.

[6] Novikoff, A. (1974) Alteration of Rocks in the Chaillu massif (République Populaire du Congo). Formation and Evolution of Clays in the Ferralitic Zone. Doctoral Thesis, University Louis Pasteur, Strasbourg, 316 p.

[7] Boissezon, P. and Gras, F. (1970) Explanatory note for the Sibiti-Est pedological map at 1/500.000. Vol. 44, Office for Overseas Scientific and Technical Research, $144 \mathrm{p}$.

[8] Muller, D. (1978) The Soils of Moungoundou (Chaillu Massif). Description of the Elements Due to the Accumulation of Sesquioxides. Office for Overseas Scientific and Technical Research, Brazzaville, $298 \mathrm{p}$.

[9] Vogt, J. and Vincent, P.L. (1966) Alteration and Overburden Terrains in the Intertropical Zone. Geological and Mining Research Office, 4, 1-111.

[10] Lecompte, P. (1988) Stone Line Profiles: Implication in Geochemical Exploration. Journal of Geochemical Exploration, 30, 35-61. https://doi.org/10.1016/0375-6742(88)90049-0

[11] Thieblemont, D., Castaing, C., Billa, M., Bouton, P. and Preat, A. (2009) Explanatory Note of the Geological Map and Mineral Resources of the Gabonese Republic at 1/1,000,000. Editions DGMG-Ministry of Mines, Petroleum and Hydrocarbons, Libreville, $384 \mathrm{p}$.

[12] Miyouna, T., Elenga, H., Boudjoumou, F., Essouli, F.O., Ibara Gnianga, A. and El hadji, S. (2019) Sedimentary Dynamics of the Pointe Noire Cover Formation in Brazzaville, Southern Republic of Congo. Africa Science, 15, 134-155.

[13] Thieblemont, D. (2013) Evidence for an Aeolian Origin of the Holocene Lateritic Surface Cover of Gabon. Quaternary International, 296, 176-197.

https://doi.org/10.1016/j.quaint.2012.06.042

[14] Miyouna, T., Malounguila Nganga, D.M., Essouli, O.F., Ndembé-Ndembé, A.J., Moussiessié, J., Kinga, M. and Boudzoumou, F. (2016) Paleoenvironmental Study of Detrital Deposits of the Congo Coastal Basin Cover Formation. Rev. CAMES, 4, No. 1.

[15] Callec, Y., Beaur, H., Paquet, F., Prognon, Issautier, B., Schoetter, J.M., Thieblement, D., Boudzoumou, F., Guillochau, F., Kebi Tsoumou, S., Dah Tolingbonon, R.H. and Nganga Lumuamu, F. (2015). Explanatory Note of the Geological Map of the Republic of Congo at 1/100000. Sheet Brazzaville. Editions Geological and Mining Research Office, $127 \mathrm{p}$.

[16] Boudzoumou, F., Malounguila-Nganga, D., Diakubuka, E., Mouanda, Moumpossa R.S., Odongo, C., et al. (1993) Notice explicative de la carte géologique de la 
république du Congo au 1:1000000. Compilation, Ministry of Mines and Energy, Congo, 1-2, 21-22.

[17] Gerard, G. (1958) Geological Map of French Equatorial Africa at 1:2,000,000 with Explanatory Note. Publication Direction of Mines and Geology, Equatorial Africa French, Brazzaville.

[18] Saaidi, E. (1991) Traité de sédimentologie. Edition Ellip, France, 393 p.

[19] Tricart, J. (1965) Principles and Methods of Geomorphology. Masson, Paris, 496 p.

[20] Walkey, A. and Black, A.I. (1934) An Examination of Degtjareff Method for Determining Soil Organic Matter and Proposed Modification of the Chromic Acid Titration Method. Soil Science, 37, 29-38. https://doi.org/10.1097/00010694-193401000-00003

[21] Folk, R. and Ward, W. (1957) A Study in the Significance of Grain Size Parameters. Journal of Sedimentary Petrology, 27, 3-26. https://doi.org/10.1306/74D70646-2B21-11D7-8648000102C1865D

[22] Passega, R. (1957) Texture as Characterististic of Clastic Deposition. AAPG Bulletin, 41, 1952-1984. https://doi.org/10.1306/0BDA594E-16BD-11D7-8645000102C1865D

[23] Losson, B. and Corbonnois, J. (2006) Detrital Sedimentation Modes New Determination Method Applied to Endokarst Fills. Geologica Belgica, 9, 257-265.

[24] Miola, R.J. and Weiser, D. (1968). Textural Parameters: An Evaluation. Journal of Sedimentary Petrology, 38, 45-53. https://doi.org/10.1306/74D71AD2-2B21-11D7-8648000102C1865D

[25] Chamley, H. (2011) Bases de la sédimentologie. 2nd Edition, Dunod, Paris, 234 p.

[26] Rivière, A. (1977) Granulometric Methods: Techniques and Interpretation. Edition Masson, Paris, New York, Barcelona, Milan, 149 p.

[27] Cailleux, A. and Tricart, J. (1959) Initiation à l'étude des sables et des galets. Center de documentation universitaire, Fascicules, Paris 3, 202 p.

[28] Cailleux, A. (1942) The Periglacial Eolian Actions in Europe. Mémoires de la Société géologique de France, 42, 176. (In French)

[29] Vatan, A. (1967) Manual of Sedimentology. Edition Technip, Paris cedex, 15, 359-399.

[30] Kra, A.C. (2016) Exoscopy of Quartz for the Paleogeographic Reconstruction of the Formations of the Eastern Onshore Basin of Cote d'Ivoire: Case of Anyama and Bonoua Localities. PhD Thesis, Université Felix Houphouët Boigny, Cocody, 265 p.

[31] Edou Minko, A., Colin, F., Trescases, J. and Lecomte, P. (1992) Lateral Alteration of the Ovala Gold Deposit Ovala Gold Deposit (Gabon), and Formation of a Surface Dispersion Anomaly. Mineralium Deposita, 27, 90-100. https://doi.org/10.1007/BF00197091

[32] Le Marechal, A. (1966). Contribution à l'étude des plateaux Batéké (Géologie, géomorphologie, hydrogéologie). Office de la Recherche Scientifique et Technique Outre-Mer, Center de Brazzaville, Service géologique, Report, 78 p.

[33] Cahen, L. and Lepersonne, J. (1948) Notes on the Geomorphology of the Western Congo. Ann du musée de turvuren Congo-belge. seriein 88, sciences géol. Vol. 1.

[34] Lepersonn, J. (1978) Geological Structure of the Interior Zaire Basin. Académie Royale des Sciences d'Outre-Mer, $33 \mathrm{p}$.

[35] Alexandre, J. (2002) Les cuirasses latéritiques et autres formations ferrugineuse tropicales exemple du Haut Katanga Méridional. Musée royal de l'Afrique Centrale-Tervuren, 
Belgium. Annales-Sciences Géologiques, 107, 129.

[36] Mercader, M.J., Martinez, J.L. and Brooks, A. (2002) The Nature of the Stone Lines in the African Quaternary Record: Archaeological Resolution at the Rainforest Site of Mosumu, Equatorial Guinéa. Quaternary International, 89, 71-96. https://doi.org/10.1016/S1040-6182(01)00082-9

[37] Assalé, F.Y.P. (2013) Sedimentological, Palynological, Geochemical and Paleoenvironmental Characterization of the Eastern Onshore Basin Formations of Côte d'Ivoire. PhD Thesis, Université Félix Houphouët Boigny, Abidjan, 361 p.

[38] Maley, J. (1987) Fragmentation of the African Rainforest and Extension of Montane Biotopes in the Late Quaternary: New Pollen and Chronological Data. Implications, Paleoclimatic, Chronological and Biogeographic. Paleoecology of Africa, 18, 307-334.

[39] Vincens, A. (1986) Pollen Diagram of a Pleistocene-Holocene Borehole from Lake Bogoria (Kenya). Review of Palaeobotany and Palynology, 47, 169-192.

https://doi.org/10.1016/0034-6667(86)90012-6 